André Gorz and the Sartrean Legacy 
This page intentionally left blank 


\section{André Gorz and the Sartrean Legacy}

Arguments for a Person-Centred Social Theory

Finn Bowring 
First published in Great Britain 2000 by

MACMILLAN PRESS LTD

Houndmills, Basingstoke, Hampshire RG21 6XS and London

Companies and representatives throughout the world

A catalogue record for this book is available from the British Library.

ISBN 978-1-349-41543-4

ISBN 978-0-230-28874-4 (eBook)

DOI $10.1057 / 9780230288744$

First published in the United States of America 2000 by

ST. MARTIN'S PRESS, INC.,

Scholarly and Reference Division,

175 Fifth Avenue, New York, N.Y. 10010

Library of Congress Cataloging-in-Publication Data

Bowring, Finn, 1969-

André Gorz and the Sartrean legacy : arguments for a person-centred social theory / Finn Bowring

p. $\mathrm{cm}$.

Includes bibliographical references and index.

1. Gorz, Andrâ. 2. Sartre, Jean Paul, 1905- 3. Socialism. 4. Existential phenomenology. 5. Labour-Philosophy. 6. Sociology. I. Title

HX44 .B664 2000

$320.53^{\prime} 15^{\prime} 092-\mathrm{dc} 21$

$99-053012$

(C) Finn Bowring 2000

Softcover reprint of the hardcover 1st edition 2000 978-0-333-77105-1

All rights reserved. No reproduction, copy or transmission of this publication may be made without written permission.

No paragraph of this publication may be reproduced, copied or transmitted save with written permission or in accordance with the provisions of the Copyright, Designs and Patents Act 1988, or under the terms of any licence permitting limited copying issued by the Copyright Licensing Agency, 90 Tottenham Court Road, London W1P 0LP.

Any person who does any unauthorised act in relation to this publication may be liable to criminal prosecution and civil claims for damages.

The author has asserted his right to be identified as the author of this work in accordance with the Copyright, Designs and Patents Act 1988.

This book is printed on paper suitable for recycling and made from fully managed and sustained forest sources.

$\begin{array}{llllllllll}10 & 9 & 8 & 7 & 6 & 5 & 4 & 3 & 2 & 1\end{array}$

$\begin{array}{llllllllll}09 & 08 & 07 & 06 & 05 & 04 & 03 & 02 & 01 & 00\end{array}$ 
For Ann, my sunshine 
This page intentionally left blank 


\section{Contents}

Preface viii

List of Abbreviations $\quad$ xii

1 Introduction to a Life 1

2 Sartre and the Existential Subject 11

3 Gorz and the Moral Conversion 32

4 An Existential Journey 67

5 Marxism, Alienation, and the End of Work 87

6 Ecological Crisis and the Limits to Economic Rationality 117

7 Critical Theory and the Sociology of the Subject 137

8 Freedom and Its Foundations: Towards a Person-Centred Social Theory 160

Afterword: A Conversation with André Gorz 186

Notes 200

Bibliography 205

Index $\quad 210$ 


\section{Preface}

Why write, what, and for whom? According to Sartre, these are the questions that every committed writer must strive to answer. If I may, for a moment, assume so grandoise a title, I should like to try and answer these questions myself.

Why write? There are perhaps as many reasons for writing as there are writers. But writing is always a way of getting to grips with things. It is obviously an essential instrument of thought and understanding which, if it is not fixed in visual words, tends to be retarded in its sophistication. It is also a way of appropriating the world, particularly that region which is most implicated in the formation of our identities as reflective and self-defining beings: that is, language. The choice, or more precisely the vocation, to write is therefore likely to have as its most fertile origin a sense of alienation profound enough to affect the individual's relationship to language and discourse. The writer, or at least the person for whom writing is an essential means of selfrealisation, is thus moved by a need not simply to act, but also to reinvent the tools, the medium and the meaning of that action.

But let's be more specific. Why write a book on the French social theorist André Gorz? In my view, Gorz is one of the most eloquent and exciting social thinkers writing today, yet the impact of his work in the English-speaking world, compared with the reception of his ideas in France, Germany and Italy, remains quite modest. A selftaught philosopher, economist and sociologist who earned his living as a journalist, Gorz has also had much greater influence on political activists, trade unionists and intellectuals than on academic figures and ideas. Though he is probably quite content with this situation, I am not. His work has too much relevance to current debates in philosophy and the social sciences to justify its neglect. The main purpose of this book is thus to give a comprehensive introduction to Gorz's life and work which will raise his profile in the academic community.

What? My starting point is Gorz's background in existential phenomenology. After a short biographical opening chapter, Chapter 2 offers a summary of the philosophical traditions which formed the broad basis for Gorz's early thinking, focusing primarily on the work of Husserl, Sartre, and Merleau-Ponty. Chapter 3 is essentially a résumé of Gorz's reworking of Sartre's existentialism, Fondements pour 
une Morale. Although the book was published in 1977, it was written several decades earlier, and for this reason it seems logical to consider it at the beginning of this book. A fascinating 600-page treatise that has yet to be translated into English, only a lengthy and demanding treatment such as the one presented in this chapter can do it justice. Chapter 4 then looks at Gorz's first published book, The Traitor. A personal and illuminating self-portrait, The Traitor is also a practical application of the central themes and methodology of Fondements. Studying this text therefore provides both further insights into Gorz's life and character, and a clarification and elaboration of his early philosophical ideas.

Chapter 5 moves on to Gorz's sociological writings, concentrating specifically on his changing approach to the study of work. Considerable space is given over to Gorz's second published book, $\mathrm{La}$ Morale de l'Histoire, not least because it also remains untranslated. The rest of this chapter discusses the theorisation of work in all Gorz's subsequent texts, including the recent Reclaiming Work. In Chapter 6 I assess Gorz's ecological critique of growth-orientated society, address certain weaknesses in elements of his thinking, and explain his attempt to reconcile ecological theory with the political demand for practical and existential autonomy. Chapter 7 then moves on to the work of Jürgen Habermas. Habermas is interesting because his diagnosis of the pathologies of contemporary capitalist societies, and his nominally dualistic use of both systems theory and hermeneutics, has much in common with Gorz's own perspective. Returning to existential phenomenology, however, I argue that Gorz's commitment to a theory of the subject is more compelling than Habermas's renunciation of the philosophy of consciousness and his over-socialised conception of the person. In Chapter 8 I conclude by rethinking Gorz's critique of Marxism and arguing for a social theory which takes account both of the existential autonomy of the individual, and of the physical-sensory foundations of the individual's experience.

For whom? To write is not only to give substance to ideas in language, but also to formulate those ideas for an intended audience. I hope that readers who are interested in and familiar with Gorz's economic and political writings will find stimulation in the depth and reach of this volume. Most famous for his critique of work and his practical proposals for the liberation of time, Gorz is not widely thought of as a philosopher. In this respect the attention given in this book to Gorz's existentialism should contribute to a richer understanding of his more recent sociological work. 
More likely, however, is that this book will be of direct interest to students and academics working in the fields of existentialism and phenomenology, on the one hand, and social theory, on the other. For the former, the book offers a reassessment and, courtesy of Gorz's Fondements pour une Morale, a revision of Sartrean existentialism, addressing in particular the paradoxes and problems which, unresolved at the time, caused many to dismiss Sartre's theorisation of freedom and morality as unworkable. It also shows how Gorz has been able to integrate his existentialism with a Marxist theory of alienation, and with certain aspects of functionalism and systems theory. For the latter, on the other hand, this volume invites a deeper interpretation of Gorz's social theory by tracing its origins to existential phenomenology and to a theory of the subject as an embodied and autonomous being. In doing so it suggests that Gorz's work constitutes a valuable contribution to mainstream debates in sociology and social theory, particularly those centred on the relationship between structures and agents.

For both audiences, therefore, what is offered is a combination of subject-centred philosophy and critical social theory, united by the conviction that neither alone is sufficient to furnish an emancipatory theory of social experience. Why, then, have I given this book the subtitle 'Arguments for a Person-Centred Social Theory'? Clearly a theoretical approach which is centred exclusively on the person cannot make sense of structural forces and constraints which, not being the intended product of individuals' will, are the traditional subject-matter of sociological enquiry. Nonetheless, it only makes sense to speak of forces and constraints which exert themselves on individuals if the speaker - the social theorists - can also account for the freedom and sensibility which, being denied by those forces and constraints, is experienced by individuals as denied. A person-centred social theory must therefore take as its ultimate, though not necessarily primary, point of reference, the perspective of a sentient, intentional, meaning-producing subject - a subject who is both a purposeful and reflective agent and, this being the absolute and inalienable foundation of all knowledge, reason and sense, a feeling and perceiving body. In doing so it must aim at elucidating how this subject experiences forms of alienation and disempowerment, at demonstrating how people live and give meaning to situations which inhibit or defy their intellectual, practical and sensory flourishing, and thus at redeeming in theory the traces of autonomy, value and self-dignity which can only be liberated in practice. This, I hope to show, is what Gorz's work does. 
Finally, let me pre-empt the anticipated objection that this is an insufficiently critical assessment of Gorz's writings. To my knowledge, with one or two notable exceptions, all the existing critical literature on Gorz is plagued by misinterpretation and ideologically driven caricature (see Bowring 1996; Lodziak and Tatman 1997: ch. 4). This is not to say that Gorz is beyond reproach. As one might expect from a political journalist and non-academic philosopher whose work spans a period of over 40 years, his writings show inevitable moments of inconsistency, deliberate breaks in continuity and changes of direction, a reliance on circumstantial, sometimes anecdotal evidence, a penchant for utopian imagining and, as Gorz himself rather modestly concedes, 'a tendency to skimp on thorough investigation and reasoning' (Gorz 1989b: 274). Nonetheless, I do not feel that what today counts as critical analysis in many scholarly circles deserves space in this book. Academic publishing has in recent years become a heavily commercialised, and writing a heavily industrialised, activity, with a premium placed on course textbooks and works which promise to provide students with a comfortable map of a fast-changing subject. Consequently, what often qualifies as critique is now simply the assignment of a given theorist to an established theoretical category or perspective, and the formulaic evaluation of this perspective from another superficially summarised position classified as opposed to it. What is gained in breadth by such discussions is almost certainly lost in depth, and while such books may help students to overcome the fear which, instead of interest or curiosity, nowadays seems to be their overriding motivation to read, something essential is surely disappearing from the process of intellectual engagement and reflective learning.

So if Gorz's social theory has any true emancipatory value - if it addresses the person as a subject and solicits the person's subjectivity - then the measure of its accomplishment must reach further than the extent of people's interest in, and familiarity with, his ideas. Instead it must rest upon the success of what he himself frequently refers to as his principal aim, namely: to 'liberate desires' and 'unfetter imaginations'. Whether he has achieved this goal is a question the reader alone can rightfully answer. But there can be no instant delegation of freedom, and only a wilful and imaginative reading of Gorz's work will reap the wealth of its full riches. 


\section{List of Abbreviations}

CER Critique of Economic Reason

CSE Capitalism, Socialism, Ecology

EP Ecology as Politics

FM Fondements pour une Morale

FWC Farewell to the Working Class

$\mathrm{MH} \quad$ La Morale de l'Histoire

PP Paths to Paradise

RW Reclaiming Work

SL Strategy for Labour

SR Socialism and Revolution

T The Traitor 